University of Nebraska - Lincoln

DigitalCommons@University of Nebraska - Lincoln

Faculty Publications, Department of Psychology

Psychology, Department of

January 2002

\title{
Using Controversial Mock Trials in "Psychology and Law" Courses: Suggestions From Participants
}

James L. Werth

University of Akron

James Harvey

University of Nebraska-Lincoln

Rebecca McNamara

University of Nebraska-Lincoln

Andrea Svoboda

University of Nebraska-Lincoln

Raina Gulbrandson

University of Nebraska-Lincoln

See next page for additional authors

Follow this and additional works at: https://digitalcommons.unl.edu/psychfacpub

Part of the Psychiatry and Psychology Commons

Werth, James L.; Harvey, James; McNamara, Rebecca; Svoboda, Andrea; Gulbrandson, Raina; Hendren, Jennifer; Greedy, Tiffany; and Leybold, Christie, "Using Controversial Mock Trials in "Psychology and Law" Courses: Suggestions From Participants" (2002). Faculty Publications, Department of Psychology. 310. https://digitalcommons.unl.edu/psychfacpub/310

This Article is brought to you for free and open access by the Psychology, Department of at DigitalCommons@University of Nebraska - Lincoln. It has been accepted for inclusion in Faculty Publications, Department of Psychology by an authorized administrator of DigitalCommons@University of Nebraska - Lincoln. 


\section{Authors}

James L. Werth, James Harvey, Rebecca McNamara, Andrea Svoboda, Raina Gulbrandson, Jennifer Hendren, Tiffany Greedy, and Christie Leybold 


\section{Using Controversial Mock Trials in "Psychology and Law" Courses: Suggestions From Participants}

\author{
James L. Werth, Jr. \\ University of Akron \\ James Harvey \\ Rebecca McNamara \\ Andrea Svoboda \\ Raina Gulbrandson \\ Jennifer Hendren \\ Tiffany Greedy \\ Christie Leybold \\ University of Nebraska-Lincoln
}

We discuss the use of a mock trial of the controversial Jack Kevorkian euthanasia case in an undergraduate psychology and law course. We provide an overview of the project, student feedback, and recommendations for improving the exercise. Based on feedback from students, we conclude that constructing a trial around a controversial topic with psychosocial issues as the foundation of a course can increase the utility of a mock trial and make the course a better learning experience.

Many schools offer courses that focus on how psychology and the law intersect and inform each other. Greene (1996) reported that there were more than 200 undergraduate courses in psychology and law in 1995. Fulero et al. (1999) stated that 15 of the top 25 ranked departments of psychology (as determined by the National Research Council) offered at least one undergraduate psychology and law course.

Several articles have described the structure of psychology and law classes (e.g., Anderson, 1992; Fulero et al., 1999; Greene, 1987, 1996; Liss, 1992; Perry, Huss, McAuliff, \& Galas, 1996; Swenson, 1983; Tomkins, 1992). Numerous other works, especially articles in this journal, have discussed active learning approaches to teaching psychology (e.g., Benjamin, 1991; Fleming, Piedmont, \& Hiam, 1990; Grosch \& Sparrow, 1992; Larsen, 1987). In this article we describe a way to use active learning techniques in teaching an undergraduate psychology and law course-specifically, using a mock trial of a current and controversial topic (controversial mock trial) throughout the class.

In our course, the students voted to use the Jack Kevorkian euthanasia case for the controversial mock trial because the instructor was familiar with end-of-life issues and could be of assistance when class members had questions. Subsequent to our course, the American Psychological Association's Working Group on Assisted Suicide and End-of-Life Decisions (2000) produced a comprehensive document that faculty could use if they were not as familiar with the subject areas but wished to use the same case.

Format of the Course

Our course followed the format described by Perry et al. (1996). The instructor devoted the first half of the class to several initial chapters of the textbook (Wrightsman, Nietzel, \& Fortune, 1998), reviewing a chapter each day. Each student made a presentation on a current event and wrote a paper in the first half of the course. The second half included coverage of the rest of the textbook along with entire days devoted to oral arguments on controversial psycholegal issues (e.g., repressed memories, predicting violence, the death penalty). After spring break, the instructor focused attention on the mock trial project, which made up $40 \%$ of the students' grades. On most days, the teacher devoted the last quarter of the class period to the mock trial.

\section{Summary of the Case}

The Kevorkian euthanasia case was ideal for a controversial mock trial because it allowed for strong psychosocial and legal arguments for both the prosecution and defense; generated a significant amount of press activity; allowed for the integration of psychological, medical, and legal literature; and tapped into strong beliefs by the participants. A detailed description of Jack Kevorkian's activities in general and of the specific case of Thomas Youk, for whose death Kevorkian was prosecuted, is beyond the scope of this article (for a discussion, see Werth, 2001). However, a brief review of the basic points is in order.

On September 17, 1998, Kevorkian performed active euthanasia (he injected the substances that caused death to oc- 
cur) on Thomas Youk, who had Amyotrophic Lateral Sclerosis (i.e., ALS or Lou Gehrig's disease). The County Medical Examiner ruled the death a homicide but Kevorkian was not arrested. However, on November 22, 1998, Kevorkian appeared on the television news program 60 Minutes (Hewitt, 1998) and discussed his involvement with Youk and provided a videotape, some of which was aired, of his interactions with Youk. The tape even showed Kevorkian injecting the lethal substances. This was the first time Kevorkian admitted to directly causing the death of any of the more than 120 people who he supposedly helped die (Jeter, 1998). Soon thereafter he was charged with first degree murder, assisted suicide, and delivery of a controlled substance (Belluck, 1999). However, because the trial judge ruled that Kevorkian could use Youk's suffering only as a defense to the assisted suicide allegation, as his attorneys had successfully in three previous trials (a fourth proceeding was declared a mistrial), prosecutors dropped the assisted suicide charge.

\section{Pretrial Preparation}

The actual Kevorkian trial, which was taking place at the same time the students were preparing for the assignment, involved only three fact witnesses; the prosecuting attorney; and Kevorkian, acting as his own lawyer. Therefore, to fully involve the 31 students in class and to highlight the controversial psycholegal issues involved, the first author allowed several more "fact" witnesses, expert witnesses, and attorneys for each side (for a list of roles, see Werth, 2001). The instructor added (a) family members for whom students could glean testimony from newspaper reports and the 60 Minutes segment ("fact witnesses," e.g., Youk's mother and brother), (b) medical "expert witnesses" for whom testimony could be based on newspaper articles and videotapes (e.g., hospice workers and physicians), and (c) mental health expert witnesses whose testimony about psychosocial issues students could gather from the published literature (e.g., psychologists and marriage and family therapists). In addition, contrary to what took place in the real case, the instructor allowed evidence of Youk's suffering.

Students rank ordered the roles they preferred to play and stated whether they wanted to be on the defense or prosecution. The instructor was able to accommodate most students' first choices. When this was not possible, students were very willing to take another role, as long as they could remain on their preferred side (i.e., prosecution or defense). Five students could not make the scheduled 4-hr evening time for the mock trial because of class or work conflicts. Therefore, these individuals played the role of jury selection attorneys and conducted their voir dire during the last regular class period prior to the night of the trial.

Because the events were ongoing during the mock trial preparation, the instructor regularly provided students with news accounts about the case, the actual trial, and postverdict occurrences. Students now will be able to collect their own material (for a bibliography of materials and Web sites, see Werth, 2001). The instructor gave attorneys for each side copies of Michigan statutes pertaining to first- and second-degree murder as well as the legal definition of mur- der; however, because it may be a better learning experience for the students to obtain this information themselves, they will not be given this material in the future. Each side could watch a videotape that contained the original 60 Minutes program (Hewitt, 1998) with the interview of Kevorkian and the death of Youk, the next evening's Nightline (Morris \& Parker, 1998) that included three experts on end-of-life issues, and a follow-up 60 Minutes (Hewitt, 1999) focusing on how people with ALS cope with the disease.

The instructor found 18 mental health, medical, legal, bioethics, and palliative care experts from across the country who agreed to be available to the students for consultation. Students had strict instructions about how to interact with the consultants because of the instructor's fear of overwhelming the professionals with requests for assistance. The instructor suggested that the students read the articles and books appropriate to roles written by the relevant consultants as well as relevant works written by another 16 experts who had published widely on end-of-life matters.

\section{Trial Procedures}

Students had 5 min each for the opening and closing statements. The attorneys knew that if the prosecution decided to use any part of the videotape of the Kevorkian program that appeared on 60 Minutes (Hewitt, 1998), then the defense could do likewise. Direct and cross-examination of witnesses were each limited to $5 \mathrm{~min}$.

The instructor recruited potential jurors from other upper level psychology courses. Finding people who could make both the jury selection time and the mock trial time proved to be difficult late in the semester and only eight students signed up, with five actually coming to both the jury selection and trial (however, other instructors who have used mock trials have not had the same difficulty). To avoid this problem we recommend that instructors recruit from several different courses well before the jury selection. The judge was an advanced clinical psychology/legal studies graduate student who had acted as the judge in previous mock trials.

\section{Mock Trial}

The trial took place in the university's law school courtroom. The instructor videotaped the trial and the jury deliberations for later use, but otherwise his only role was to monitor the time and inform the judge when the 5-min direct examination and 5-min cross-examination per witness was over. The entire trial took $3 \mathrm{hr}$, with a 10-min break after the prosecution rested its case. In the posttrial follow-up, both jurors and class members were consistent in rating the effectiveness of the witnesses and attorneys for the prosecution and for the defense. Clearly, those witnesses who spent time on their testimony and were prepared for the occasionally difficult cross-examination were most effective, and those attorneys who had worked with their witnesses on developing both direct examination and cross-examination questions were most effective. 
Because of time constraints, the jury could deliberate for only $30 \mathrm{~min}$. The result was a hung jury.

While the jury was deliberating, the class members filled out questionnaires about the mock trial. The next class day after the trial, the students spoke about the mock trial project. These data provide the basis for our recommendations regarding how the instructor could have better used the mock trial as a teaching tool and practical learning experience for the class members.

\section{Mock Trial Data}

\section{Student Questionnaires}

Immediately following the mock trial, the instructor distributed a questionnaire to all the students. The survey focused on numerous aspects of the course and the preparation for the mock trial. Comparisons of interest were between the defense and prosecution groups on a series of four yes-no questions. Because the number of students responding varied between 22 and 29 (some students did not clearly answer yes or no on all items), we analyzed the data using chi-square tests. Support for the idea of euthanasia did not significantly differ between groups, $\chi^{2}(1, N=22)=1.32, p>.05$. However, significant differences were found on whether students believed Kevorkian was guilty before the trial preparation process, $\chi^{2}(1, N=24)=4.20, p<.05$; whether he was guilty after the process, $\chi^{2}(1, N=26)=18.62, p<.001$; and whether the student believed jury nullification ("the implicit power [juries have] to acquit defendants despite evidence and judicial instructions to the contrary," Horowitz \& Willging, 1991, p. 165) was appropriate in any case, $\chi^{2}(1, N$ $=29)=9.89, p<.005$. Students who were on the defense team were significantly less likely to think Kevorkian was guilty before or after the trial and were significantly more likely to believe jury nullification was acceptable.

Students also answered open-ended questions about how they would make the mock trial a better learning experience. The primary suggestion (mentioned by 13 of the 29 respondents) was to devote more time to the mock trial by starting earlier in the semester and spending more class time on group activities and reviewing court procedures (especially the use of objections). The students also made it clear that they wanted guidance on what the instructor expected of them in their roles as witnesses and attorneys (i.e., they wanted to have models for their roles). Some specific suggestions were to have experts come into class to debate, bring in attorneys to discuss trial strategies, and conduct a mock direct examination and cross-examination of the instructor. Several students also wanted to see parts of a videotape of a previous mock trial.

Finally, in terms of what the students learned from participating in the trial itself, class members stated unequivocally that the mock trial was the most interesting part of the class (although it was also the most labor intensive), they appreciated the opportunity to see how the different aspects of material discussed in class came together (although this aspect could be improved through the changes we recommend subsequently), and they recommended keeping and building on this part of the course. Given that all the suggestions they provided involved spending more time on the mock trial and related aspects and no one suggested dropping the activity or devoting less time, the clear consensus is that the activity was a positive and effective approach to teaching about the interplay between psychology and the law.

\section{Student Papers}

Students wrote papers that described the role they played in the mock trial (e.g., mental health expert witness, cross-examination attorney, and Youk's wife) and discussed three psycholegal issues related to their role (for exact description, see Perry et al., 1996). The instructor suggested end-of-life issues and jury nullification. Some students found articles that involved experiments using euthanasia as a test case for nullification (Finkel, Hurabiell, \& Hughes, 1993; Horowitz, 1985).

The topics discussed differed somewhat based on whether the students were on the prosecution or defense team. For the prosecution ( $N=14$ papers), the most commonly covered issues were end-of-life decisions or hastened death $(n=$ $11)$, expert witnesses $(n=8)$, ethics-morality in the legal context $(n=4)$, and jury nullification $(n=4)$. For the defense ( $N=14$ papers), the primary topics were end-of-life decisions or hastened death $(n=10)$, jury nullification $(n=8)$, fact witnesses $(n=6)$, and expert witnesses $(n=3)$.

Because everyone on each team needed to know about the end-of-life issue, it is not surprising that it was the most popular choice. The prosecution's case rested on the facts and the use of expert witnesses to discount the strategy of the defense that Youk's only option was euthanasia and that he made a free choice in calling Kevorkian. The split between ethics-morality and jury nullification may reflect a decision on the part of the prosecution to say that euthanasia is a legal issue, and not a moral one. On the other side, jury nullification was the key tactic for the defense, and the use of emotional "fact" witnesses (i.e., Youk's mother, brother, wife, and good friend) was instrumental to counter the hard, cold fact witnesses for the prosecution (i.e., police officer, county medical examiner, and deputy forensic pathologist). Expert witnesses for the defense attempted to put reasonable doubt in the juror's minds about how clear-cut the options were for Youk, his family, and Kevorkian.

\section{Expert Consultant Feedback}

After the trial, the instructor contacted all 18 consultants and asked a series of questions about the experience. Only 3 of the 16 experts who responded to the follow-up query said that a student had contacted them. All 16 said that they would be willing to act in such a role again and that it appeared as if the mock trial would be a good teaching tool. Several expressed disappointment that they had not been contacted, and a few asked additional questions of the instructor about the trial itself. In retrospect, the instructor may have intimidated the students by placing too many restrictions on them in terms of how they could interact with the consultants. 


\section{Recommendations for Better Use of the Mock Trial}

Based on the feedback from the students, as well as the instructor's observation of the preparation process and the events of the trial, we suggest that the teacher introduce the controversial mock trial project at the beginning of the course and integrate it throughout the term. We recognize that following this suggestion would necessarily mean some class time would need to be shifted from covering specific material contained in the course book or packet; however, the topic selected for the mock trial should be one that can be incorporated into existing course material. In addition, if the controversial area selected is one in which psychologists have published articles or books, the American Psychological Association has convened a working group or task force, or the American Psychological Association has prepared amicus curiae briefs, there should be sufficient opportunity to balance any legal discussion with the psychological aspects.

Our other main suggestion for this part of the course is that actual attorneys give presentations to the class with descriptions and examples of what happens in court with the jury selection process (voir dire), opening statements, direct examination, cross-examination, objections and responses to the examinations, and closing arguments. Although students could fulfill a course requirement by attending a jury trial in the first half of the course (see Perry et al., 1996), the court docket for this particular semester did not allow many students to take advantage of this opportunity.

Regardless of whether many students attend an actual trial, we believe that it would be helpful to have an in-class demonstration of how attorneys work with witnesses on the stand. The instructor could be a witness in a role related to the mock trial case (perhaps once for the prosecution and once for the defense so that the students can see the differences in the ways an attorney may conduct examination and cross-examination), and the two attorneys would play the roles of prosecution and defense lawyers (or, if a civil case is used, the plaintiff's and defendant's attorneys). There should be a judge to rule on objections raised by attorneys. This section should come early in the semester so that students have a chance to incorporate the information they receive into the parts they will play and the papers they will write.

Because the emphasis on the mock trial and related activities may give students the impression that litigation is the primary way in which law and psychology intersect, the instructor should emphasize that psychologists do more than act as expert witnesses and provide evaluations for the courts. Psychology and law courses cover topics as diverse as how prisoners can be treated, psychotherapist-client and physician-patient relationships, and family arrangements. The materials the instructor uses in the course should highlight the way the two disciplines inform each other by including topics such as sexual harassment, victim rights, the treatment of eyewitnesses by the police and attorneys, and decision-making competence.

Moving back to specific recommendations related to the mock trial activity, we think the idea behind having expert consultants was sound. However, few students took advantage of this opportunity. In the future, we suggest that in- structors provide students with latitude in terms of contacting the consultants and ensure the experts know that they are free to set limits with students. We also believe that by introducing the topic early in the term so that students become familiar with the subject and have a chance to reflect on, and research, questions and issues, the students will feel more able to correspond intelligently with the consultants.

We also believe that the papers were an important part of the experience. They forced the students to examine and discuss a variety of issues; therefore demonstrating the work they had done in preparation for their respective roles. The paper was worth $85 \%$ of the grade for the mock trial project. Team participation, as rated by other team members, was worth $10 \%$, and their performance (i.e., whether the material they presented was accurate and appropriate) was worth $5 \%$.

\section{Conclusions}

We have described the controversial mock trial in which we participated and, based on feedback from all participants, we have provided recommendations for improving on what was already, according to student feedback, a successful endeavor. We are convinced that using a mock trial is a valuable learning tool for students and focusing on a controversial topic, which allows students with strong beliefs to take a side and also provides strong psychosocial arguments on several sides of the issue, can provide students with valuable learning opportunities. Using a mock trial to depict a controversial issues could be useful in social psychology, psychology of prejudice-discrimination, psychology of women, and adolescent psychology courses. Regardless of the type of course, we believe that using the approach we suggest in this article would make using a controversial mock trial an even better experience for everyone involved.

\section{References}

-Anderson, D. D. (1992). Using feature film as tools for analysis in a psychology and law course. Teaching of Psychology, 19, 155-158.

Belluck, P. (1999, March 27). Kevorkian convicted of second degree murder. New York Times, p. A1.

Benjamin, L. T., Jr. (1991). Personalization and active learning in the large introductory psychology class. Teaching of Psychology, 18, $68-74$.

-Finkel, N. J., Hurabiell, M. L., \& Hughes, K. C. (1993). Right to die, euthanasia, and community sentiment: Crossing the public/private boundary. Law $\mathcal{E}$ Human Behavior, 17, 487-506.

-Fleming, M. Z., Piedmont, R. L., \& Hiam, C. M. (1990). Images of madness: Feature films in teaching psychology. Teaching of Psychology, 17, 185-187.

Fulero, S. F., Greene, E., Hans, V., Nietzel, M. T., Small, M. A., \& Wrightsman, L. S. (1999). Undergraduate education in legal psychology. Law Eु Human Behavior, 23, 137-153.

-Greene, E. (1987). An undergraduate course in psychology and the law. Teaching of Psychology, 14, 238-239.

Greene, E. (1996). Teaching materials for undergraduate legal psychology courses. Retrieved October 2, 2000 from http://www.unl.edu/ ap-ls/handbook.htm

Grosch, J. W., \& Sparrow, J. E. (1992). Detecting deception: A classroom demonstration. Teaching of Psychology, 19, 166-168. 
Hewitt, D. (Executive Producer). (1998, November 22). Death by doctor. 60 minutes. New York: CBS.

Hewitt, D. (Executive Producer). (1999, February 28). ALS: Choosing life. 60 minutes. New York: CBS.

Horowitz, I. A. (1985). The effect of jury nullification instruction on verdicts and jury functioning in criminal trials. Law $\mathcal{B}$ Human Behavior, 9, 25-36.

-Horowitz, I. A., \& Willging, T. E. (1991). Changing views of jury power: The nullification debate, 1787-1988. Law $\mathcal{E}$ Human Behavior, 15, 165-182.

Jeter, J. (1998, November 21). With videotape, Kevorkian invites new charge. The Washington Post, p. A5.

Larsen, J. D. (1987). Prisoner's dilemma as a model for understanding decisions. Teaching of Psychology, 14, 230-231.

Liss, M. B. (1992). Psychology and law courses: Content and materials. Law $\mathcal{E}$ Human Behavior, 16, 463-471.

Morris, D., \& Parker, G. (Producers). (1998, November 23). Nightline. Washington, DC: ABC.

-Perry, N. W., Huss, M. T., McAuliff, B. D., \& Galas, J. M. (1996). An active-learning approach to teaching the undergraduate psychology and law course. Teaching of Psychology, 23, 76-81.

- Swenson, E. V. (1983). Incorporating law into the undergraduate psychology curriculum. Teaching of Psychology, 10, 119-120.

Tomkins, A. J. (1992). The role of applied psychology courses in the undergraduate psychology curriculum: "Psychology and Law" courses as a case in point. Unpublished manuscript. Available from the author:
Public Policy Center, 119 CBA, University of Nebraska, Lincoln, NE 68588-0473.

Werth, J. L., Jr. (2001). Using the Youk-Kevorkian case to teach students about euthanasia and other end-of-life issues. Death Studies, $25,151-177$.

Working Group on Assisted Suicide and End-of-Life Decisions. (2000). Report to the Board of Directors of the American Psychological Association [Report]. Washington, DC: American Psychological Association. Retrieved October 2, 2000 from http://www.apa.org/pi/aseolf.html

Wrightsman, L. S., Nietzel, M. T., \& Fortune, W. H. (1998). Psychology and the legal system (4th ed.). Pacific Grove, CA: Brooks/Cole.

\section{Notes}

1. We thank Randolph Smith, Daniel J. Holdwick, Jr., James R. Rogers, and three anonymous reviewers for their helpful comments on an earlier version of this article.

2. Send correspondence and requests for a list of other controversial cases that instructors could incorporate in the manner we advocate; suggestions about how to incorporate material into the coverage of chapters in the Wrightsman, Nietzel, and Fortune (1998) text; and the bibliography discussed herein to James L. Werth, Jr., Department of Psychology, 3rd Floor, Polsky Building, University of Akron, Akron, OH 44325-4301; e-mail: Jwerth@uakron.edu. 